\title{
A Potential Substitute to Fish Meal: The Veined Rapa Whelk,
}

\section{Rapana Venosa}

\author{
Sahin T*, Yilmaz S and Ergun S \\ Marine Sciences and Technology Faculty, Çanakkale Onsekiz Mart University, Turkey \\ *Corresponding author: Sahin T, Marine Sciences and Technology Faculty, Çanakkale \\ Onsekiz Mart University, Turkey, Tel: +90 28621800 18/4050; Email: \\ tolgasahin@comu.edu.tr
}

\section{Review Article \\ Volume 2 Issue 3}

Received Date: May 07, 2018

Published Date: May 28, 2018

\section{Abstract}

In aquaculture industry, fish meal is considered to be the most important raw material in aquatic feeds, due to high quality and quantity of its protein. The necessity of fish meal has been increasing as the aquaculture industry grows. However, as the rapid growth of aquaculture sector has created a pressure on the sources of fish meal, a decrease in relevant fish populations have been encountered and fish meal price have increased. To date, several raw materials have been therefore investigated in order to replace fish meal in aquafeed and reduce production costs; but yet, not an exact one has been found to completely replace it. Taking into consideration the current situation, any raw material to replace fish meal has been of particular importance. Accordingly, regarding its high protein content and balanced amino acid profile, the veined Rapa whelk meal has been reviewed to replace the fish meal in aquafeeds.

Keyword: Rapana venosa; Fish meal; Aquafeed; Molluscan

\section{Introduction}

The aquaculture industry has been considered as the most promising future protein source for human consumption in the near future [1]. Ipso facto, depending on the increasing demand on aquaculture products, the amount of production obtained through aquaculture in the world has reached up to 106 million tonnes [2] and is expected to be much more in a close future. In parallel with this increment, aquafeed necessity has also been increasing evenly in order to supply the need for aquaculture sector.

Being considered as comprising the most nutritious and digestible ingredients for farmed fish, fish meal represents a great importance for the aquafeed industry [3]. However, the recent pressure on fishing activities in order to obtain required fish meal possesses a danger to population dynamics of the ecosystem for distant future and it is obvious that live stocks for fish meal are gradually going to be insufficient. As a result of lack of natural stocks used in aquafeed industry, the price of fish meal has also gone up. The amount of fishmeal used in aquaculture has therefore resulted in a downward slope to be able to offset their high prices, and being used more selectively as strategic ingredients at lower concentrations to meet the specific requirements of the target species [3], particularly larval fish and brood stock. Therefore, the presence of an animal or plant resource 


\section{International Journal of Oceanography \& Aquaculture}

that can be an alternative to fish meal is of great importance.

\section{Alternative Protein Sources}

Researchers are recently trying to find out alternative protein sources in aquaculture diets. Numerous studies have been carried out on aquatic species in order to determine whether plant or animal based alternative protein sources may partially or completely replace fish meal in aquafeed.

Researchers have been lately focusing on the high availability and digestibility besides low price protein sources for fish meal substitutes. In this particular; it was reported by Cho, et al. [4] that, $40 \%$ fish meal could be replaced by feather meal [5], $20 \%$ by meat $\&$ bone meal [6], $60 \%$ by meat meal [7], $50 \%$ poultry by-product meal $[8,9], 50 \%$ by defatted soybean meal [10] or $20 \%$ by defatted soybean meal [11], 20\% hazelnut meal [12] 40\% by corn gluten meal $[13,14]$, soybean meal and $46 \%$ by defatted soybean meal in combination with blood meal, corn gluten meal and blue mussel meat [15] in the different fish species feeds.. In the view of some other researches carried on different species, it has also been found that the substitution of the field pea and narrowleafed lupin to fish meal have been shown to be effective in Atlantic salmon feeds [16]; Spirulina found to be replacing up to $40 \%$ of the fish meal protein in tilapia diets [17], high levels of plant protein sources has been found to successfully replace fish meal in diets of ongrowing Senegalese sole [18] and the list grows. When the aforementioned or previous researches taken into account; even though a considerable number of animal or plant based meals have been evaluated as potential protein sources in aquaculture feed, only a few are regarded as suitable or applicable [19].

Most of the plant origin meals include lower quality and quantity of protein and they may have lower palatability, deficient essential amino acid \& fatty acid profile and might also contain higher levels of indigestible carbohydrates and anti-nutritional factors [20]. Within plant based protein sources, only soybean meal has been efficiently evaluated as major protein source in aquafeed and commonly used in aquafeed industry. Together with other nutritional benefits, soy meal has a high quality and quantity of protein, high digestibility and the best amino acid profile of the plant protein sources investigated [21]. However, some anti-nutritional factors of soybean meal and/or species-specific features of cultured animal limit the use of soybean meal in aquafeed. Moreover, according to Sánchez-Muros, et al. [21], increased soy cultivation causes the deforestation of areas with a high biological value [22,23], high water consumption [24], the utilisation of pesticides and fertilisers [22], and transgenic varieties [25], which cause significant environmental deterioration [23].

Therefore, attempts to find alternative protein sources continue to increase with great momentum. In this regard, some insect species are lately being investigated intensively as alternative protein sources in aquafeed. Several studies have been conducted on Clariasgariepinus [26,27], Clariasanguillaris [28], Catlacatla, Labeorohita, Cirrhinusmrigala, Hypophthalmychthys molitrix [29], Orechromisniloticus [30], Oreochromismossambicus [31], Oncorhynchus mykiss [32], Psetta maxima [33], Oreochromis sp. [34], Salmo salar [35], Dicentrarchuslabrax [36], Pagellusbogaraveo [37], Sparusaurata [38] and some positive results (up to 10$30 \%$ replacement of fish meal) obtained from the studies conducted. However, based on the literature reviewed it has also been mentioned that the nutritional composition of insects vary significantly and highly dependent on the species cultivated, developmental stage of the organism and culture media of the insects; their lipid, protein and mineral composition are all highly variable, even within a taxon at the same developmental stage [39]. For instance, the lipid concentration ranges between 15 and $35 \%$ for black soldier fly larvae and between 9 and 26\% for housefly maggots according to dry matter basis analysis and such a wide variation seems to be an obstacle when formulating feeds at an industrial scale [39]. Besides; high chitin levels, lack of indispensable amino acids, lower protein digestibility ratios and fatty acid compositions seem to be other limiting factors on the use of insect meals.

When taken into consideration the unfavourable properties of above mentioned meals and high fishmeal prices, investigation of new alternative protein sources are still being seen rational and necessary.

\section{The Veined Rapa Whelk Rapana venosa}

As the second largest phylum in the animal kingdom, Mollusca contains a great number of species and the members of the phylum are predominantly aquatic [40]. Some of those species' meals are commonly used (both edible and non-edible parts) in aquafeed or evaluated as fresh flesh in aquaculture more particularly in broodstock nutrition owing to their nutritional values. In this particular, literature reports that Molluscs are important 


\section{International Journal of Oceanography \& Aquaculture}

dietary sources of fat soluble vitamins (E, D3 and A), essential fatty acids [41], protein [40] and minerals and therefore are quality raw materials for fish feed. As being distributed worldwide and easy available, several species of Molluscs might be proper candidates to substitute fish meal.

Within Molluscan species, the veined Rapa whelk is a marine origin gastropod which is native to coastal waters of the Sea of Japan, Yellow Sea, Bohai Sea, and the East China Sea to Taiwan [42,43]. Over the years, it was transported by ballast water of vessels and/or hull fouling and spread throughout the North Seas $[44,45]$, Black Sea, Adriatic Sea, Azov Sea, Aegean Sea, Chesapeake Bay on the East Coast of the United States and the Rio de la Plata between Uruguay and Argentina [46]. Being as one of the worst invader species worldwide [47], it is well known for its high fecundity rate, earlier sexual maturity $[48,49]$, rapid growth rate, longevity [50], high tolerance to fluctuating salinities \& water temperature, oxygen deficiency and water pollution $[51,52]$.

The Veined Rapa whelk feeds mainly on other Molluscan species such as oysters, mussels or clams [5355], thus leads to rapid decrease of bivalve molluscan fauna in the ecosystem [56]. Because of predation behaviour over bivalves, veined Rapa whelk severely threats the food web where it establishes. According to the report on current and future management of Black Sea fisheries [57] it has been stated that veined Rapa whelk is in the position of "a predator without enemy" thus exercising great pressure on blue mussel (Mytilus galloprovincialis), stripped venus clam (Chamelea gallina), noble oyster (Ostrea edulis) populations as well as many other shellfish species' populations and seriously endangering the ecological balance of the Black Sea. Since bivalve molluscs are nutritional sources of various fish species, decreases in their stocks directly affect other fish stocks either. Therefore preventing the growth of excessive populations of veined Rapa whelk is of significant importance [53]. Especially for the last ten years a remarkable fishery has taken place particularly in Turkey and Bulgaria for its economic value as it is consumed as human food in Eastern Asia [58].

The Veined Rapa whelk has high protein rate (Table 1) and satisfactory amino acid content (Table 2). Even though the nutritional values may vary depending on the season, feeding habits or habitat of the organism; veined Rapa whelk provides a relatively consistent nutritive value year-round. Consequently, when considering the parameters such as rapid growth of its population, its broad distribution around the world waters, lack of its predators, apprehensive reports on its ecological effects and its nutritional value; veined Rapa whelk might be a proper source in aquafeed.

\begin{tabular}{|c|c|}
\hline Rapana venosa meal & g/100g (dry matter based) \\
\hline Crude Protein & 72.09 \\
\hline Crude Lipid & 1.89 \\
\hline Ash & 3.82 \\
\hline Moisture & 7.83 \\
\hline
\end{tabular}

Table1: Proximate analysis of veined Rapa whelk meal*. ${ }^{*}$ Our Laboratory reports

As protein is a valuable component in aquafeed, it must be in adequate amounts for the cultured organism. In order to meet the requirements of each species, proteins, which are formed by individual amino acids, must include all indispensable amino acids that cannot be synthesized by the fish. In this regard, veined Rapa whelk meal is an outstanding source because of its very high protein and balanced amino acid content.

\begin{tabular}{|c|c|c|c|c|c|c|}
\hline Amino acid & R.venosa meal $^{\mathbf{a}}$ & Anchovy meal $^{\mathbf{b}}$ & Menhaden meal $^{\mathbf{b}}$ & Herring meal $^{\mathbf{b}}$ & Krill meal $^{\mathbf{c}}$ & Soybean meal $^{\mathbf{d}}$ \\
\hline L-Lysine & 42.2 & 61.5 & 61.2 & 58 & 43.6 & 33.0 \\
\hline L-Threonine & 23.8 & 27.8 & 32.0 & 29 & 21.1 & 17.9 \\
\hline L-Valine & 16.2 & 41.1 & 42.5 & 40 & 25.4 & 24.3 \\
\hline L-Leucine & 46.6 & 62.8 & 56.1 & 60 & 38.7 & 41.9 \\
\hline L-Methionine+L-Cystine & 24.2 & 22.5 & 29.8 & 26 & 26.1 & 16.5 \\
\hline L-Isoleucine & 19.4 & 39.5 & 36.2 & 35 & 25.0 & 23.3 \\
\hline L-Phenylalanine & 23.1 & 33.5 & 29.3 & 30 & 37.0 & 26.6 \\
\hline L-Histidine & 19.1 & 18.6 & 14.6 & 16 & 10.6 & 14.1 \\
\hline L-Arginine & 33.0 & 45.6 & 49.9 & 50 & 33.3 & 39.0 \\
\hline
\end{tabular}

Table 2: Amino acid profile of Rapana venosa meal (g/1000g, dry matter). aOur Laboratory reports; bAnderson et, al. [59]; cXu et, al. [60]; dKarr-Lilienthal et, al. [61] 


\section{International Journal of Oceanography \& Aquaculture}

Essential amino acid profile of the veined Rapa whelk appears to be relatively lower than the fish meal. However, since the fish meal prices has grown apace, the use of fish meal in aquafeed decreased and the meal of fish by-products [62-66] and soybean meal increased on the contrary. Considering the fact that co-product fish meal represents only $33 \%$ of total fish meal supply [67] and soybean meals have lower quality and quantity of protein than fish meal and the limitations on their usage in aquafeed due to some unfavourable properties, the substitution of veined Rapa whelk meal seems reasonable.

In terms of lipid content even though veined Rapa whelk meal has a well-balanced fatty acid composition, it is deficient alone for the diet (Table 3). However, it is obvious that this deficiency is not a problem as it is not used as a major lipid source in fish feed.

\begin{tabular}{|c|c|c|c|}
\hline Trivial name & Systematic name & Fatty acid & R. venosa \\
\hline Myristic acid & Tetradecanoic Acid & $14(0)$ & 3.16 \\
\hline Pentadecenoic acid & 2-Pentadecenoic acid & $15(1 \mathrm{n}-13)$ & 1.01 \\
\hline Palmitic acid & Hexadecanoic Acid & $16(0)$ & 13.03 \\
\hline Palmitoleic acid & 9-Hexadecenoic Acid & $16(1 \mathrm{n}-7)$ & 1.12 \\
\hline Stearic acid & Octadecanoic Acid & $18(0)$ & 14.48 \\
\hline Oleic acid & 9-Octadecenoic Acid & $18(1 \mathrm{n}-9)$ & 3.62 \\
\hline Linoleic acid & 9,12-Octadecadienoic Acid & $18(2 \mathrm{n}-6)$ & 2.95 \\
\hline Paullinic acid & 13,-Eicosenoic acid & $20(1 \mathrm{n}-7)$ & 12.96 \\
\hline Dihomolinoleic Acid & 11,14-Eicosadienoic Acid & $20(2 \mathrm{n}-6)$ & 8.95 \\
\hline Arachidonic acid & 5,8,11,14-Eicosatetraenoic Acid & $20(4 \mathrm{n}-6)$ & 11.51 \\
\hline Timnodonic Acid (EPA) & 5,8,11,14,17-Eicosapentaenoic Acid & $20(5 \mathrm{n}-3)$ & 4.78 \\
\hline Docosa-5,13-dienoic acid & 5,13-Docosadienoic acid & $22(2 \mathrm{n}-9,17)$ & 6.25 \\
\hline Clupanodonic Acid & 7,10,13,16,19-Docosapentaenoic Acid & $22(5 \mathrm{n}-3)$ & 7.17 \\
\hline Cervonic Acid (DHA) & $4,7,10.13 .16,19-$-Docosahexaenoic Acid & $22(6 \mathrm{n}-3)$ & 9.01 \\
\hline
\end{tabular}

Table 3: Fatty acid composition of Rapana venosa meal (\% of total fatty acids) extracted using Chloroform: Methanol solution $(2: 1)^{*}$.

${ }^{*}$ Our Laboratory reports

\section{Conclusion}

A proper diet must provide all essential nutrients in adequate proportions. However, the nutritional content provided by each raw material is also different, as the requirements of each species are different. For this reason, when feeds are formulated, the specific needs of each organism considering their developmental stages are determined and steps are taken. The most important thing to note at this point is the necessity of essential nutrients in feed, therefore in raw materials. Raw materials that contain the desired characteristics and quantity of nutritional components are considered to be of high quality and are widely used. However, no more quality protein source has been found to replace fish meal in aquafeed yet. In this regard, it still seems rational to use other aquatic organisms in aquafeed as these organisms are thought to have the required nutritional content that aquaculture species may need. When taken in the account the idea mentioned above, the use of whelks as protein source in aquafeed has been become reasonable.
In the literature, no previous studies have been encountered on the use of veined Rapa whelk meal in aquafeed. There is only one study [68] has been reported on the use of Rapana rapiformis meal which belongs to the same genus. In that study, non-edible parts of Chicoreus virgineus and Rapana rapiformis species' were used as major protein sources in diets of Penaeus indicus juveniles and Rapana rapiformis meal has been found to be able to substitute in the diet up to $30 \%$ without causing any loss in survival or less growth. In that study, only non-edible portions of the organism were used. However, during the fishery of veined Rapa whelk, smaller individuals are also captured but not evaluated as export products due to lower price and market demand. For this reason both edible, non-edible processing residues (digestive gland, gonadal regions etc.) and off-sized whelks might also be evaluated in aquafeed industry.

Raw materials used in feeds are expected not only to be a source of protein that provides better growth, but they are also expected to provide features such as enhanced reproduction, disease protection, environmental stress 


\section{International Journal of Oceanography \& Aquaculture}

resistance, better coloration and delicious meat. In this regard, it has been previously reported by Luo, et al. [69] that the hemocyanin and its functional units from veined Rapa whelk showed phenol oxidase activity [70,71], antimicrobial activity [70,72], antiviral activity [73], antitumor activity [74,75] and healing properties on skin burns [76].

Considering aforementioned properties of veined Rapa whelk and the gap in the literature it has been thought that veined Rapa whelk might be evaluated in aquafeed as protein source. However, a complete analysis of chemical composition should be carried out in order to determine whether it contains anti-nutritional components; and digestibility analysis should be done for a better understanding of bio-availability of its protein.

\section{References}

1. (2006) Food and Agriculture Organization of the United Nations (FAO). State of world aquaculture. FAO Fisheries Technical Paper, FAO, Rome, 500: 134.

2. (2015) Food and Agriculture Organization of the United Nations (FAO). Fish Stat J: a tool for fishery statistics analysis. Available from: http://faostat3.fao.org/home/E (accessed 04.05.18.).

3. (2016) The State of World Fisheries and Aquaculture 2016. Contributing to food security and nutrition for all. Rome, pp: 200.

4. Cho SH, Lee SM, Park BH, Park IS, Choi CY, et al. (2005) Effect of partial replacement of fish meal with squid liver meal TM in the diet on growth and body composition of juvenile olive flounder (Paralichthys olivaceus) during winter season. Fish Aquatic Sci 8(2): 65-69.

5. Kikuchi K, Furuta T, Honda H (1994) Utilization of feather meal as a protein source in the diet of juvenile Japanese flounder. Fisheries Sci 60(2): 203-206.

6. Kikuchi K, Sato T, Furuta T, Sakaguchi I, Deguchi Y (1997) Use of meat and bone meal as a protein source in the diet of juvenile Japanese flounder. Fisheries Sci 63: 29-32.

7. Sato T, Kikuchi K (1997) Meat meal as a protein source in the diet of juvenile Japanese flounder. Fisheries Sci 63: 877-880.
8. Turker A, Yigit M, Ergun S, Karaali B, Erteken A (2005) Potential of poultry by-product meal as a substitute for fishmeal in diets for Black Sea turbot Scophthalmus maeoticus: Growth and nutrient utilization in winter. Isr J Aquac - Bamidgeh 57: 4961.

9. Yigit M, Erdem M, Koshio S, Ergün S, Türker A, et al. (2006) Substituting fish meal with poultry by-product meal in diets for black Sea turbot Psetta maeotica. Aquac Nutr 12: 340-347.

10. Kikuchi K, furuta T, Honda H (1994) Utilization of soybean meal as a protein source in the diet of juvenile Japanese flounder, Paralichthys olivaceus. Aquacult Sci 42: 601-604.

11. Yigit M, Ergün S, Türker A, Harmantepe B, Erteken A (2010) Evaluation of soybean meal as a protein source and its effect on growth and nitrogen utilization of black sea turbot (Psetta maeotica) juveniles. J Mar Sci Tech 18: 682-688.

12. Ergün S, Yigit M, Türker A, Harmantepe B (2008) Incorporation of soybean meal and hazelnut meal in diets for Black Sea turbot (Scophthalmus maeoticus). Isr J Aquac - Bamidgeh 60(1): 27-36.

13. Kikuchi K (1999) Partial replacement of fish meal with corn gluten meal in diets for Japanese flounder Paralichthys olivaceus. J World Aquacult Soc 30: 357363.

14. Bulut M, Yiğit M, Ergün S, Kesbiç O, Acar Ü, et al. (2014) Incorporation of corn gluten meal as a replacement for fish meal in the diets of two banded seabream (Diplodus vulgaris) juveniles. Int J of Agri Science 4: 60-65.

15. Kikuchi K (1999) Use of defatted soybean meal as a substitute for fish meal in diets of Japanese flounder (Paralichthys olivaceus). Aquaculture 179(1-4): 3-11.

16. Carter C (1998) Fish Meal Replacement in Aquaculture Feeds for Atlantic Salmon, Fisheries Research and Development Coporation. Univeristy of Tasmania, pp: 136.

17. Olvera-Novoa M, Dominguez-Cen L, Olivera-Castillo L, Martínez-Palacios CA (1998) Effect of the use of the microalga Spirulina maxima as fish meal replacement in diets for tilapia, Oreochromis mossambicus (Peters), fry. Aquac Res 29: 709-715. 


\section{International Journal of Oceanography \& Aquaculture}

18. Cabral E, Fernandes T, Campos S, Castro-Cunha M, Oliveira M, et al. (2013) Replacement of fish meal by plant protein sources up to $75 \%$ induces good growth performance without affecting flesh quality in ongrowing Senegalese sole. Aquaculture 380: 130138.

19. Davis D (2015) Feed and feeding practices in aquaculture. Wood head publishing.

20. Carter C, Hauler R (2000) Fish meal replacement by plant meals in extruded feeds for Atlantic salmon, Salmo salar L. Aquaculture 185: 299-311.

21. Sánchez-Muros MJ, Barroso FG, Manzano-Agugliaro F (2014) Insect meal as renewable source of food for animal feeding: a review. J CleanProd 65: 16-27.

22. Carvalho R (1999) A Amazônia rumo ao 'ciclo da soja'. In: Amazônia Papers No. 2. Programa Amazônia, Amigos da Terra, São Paulo, Brazil, p: 8. URL: http://www. amazonia.org.br.

23. Osava M (1999) Environment-Brazil: Soy Production Spreads, Threatens Amazon. Inter Press Service.

24. Steinfeld H, Gerber P, Wassenaar T, Castel V, et al. (2006) Livestock's Long Shadow: Environmental Issues and Options. FAO, Rome, Italy, pp: 1-26.

25. Garcia MA, Altieri MA (2005) Transgenic crops: implications for biodiversity and sustainable agriculture. Bull Sci Technol Soc 25(4): 335-353.

26. Alegbeleye WO, Obasa So, Olude 00, Otubu K, Jimoh W (2012) Preliminary evaluation of the nutritive value of the variegated grasshopper (Zonocerus variegatus L.) for African catfish Clarias gariepinus (Burchell. 1822) fingerlings. Aquac Res 43: 412-420.

27. Ng WK, Liew FL, Ang LP, Wong KW (2002) Potential of mealworm (Tenebrio molitor) as an alternative protein source in practical diets for African catfish, Clarias gariepinus. Aquac Res 32: 273-280.

28. Achionye-Nzeh C, Ngwudo O (2003) Growth response of Clarias anguillaris fingerlings fed larvae of Musca domestica and soyabean diet in the laboratory. Biosci Res Commun 15: 221-223.

29. Rangacharyulu P, Giri S, Paul B, Yashoda K, Rao RJ, et al. (2003) Utilization of fermented silkworm pupae silage in feed for carps. Bioresource Technol 86(1): 29-32.
30. Ajani E, Nwanna L, Musa B (2004) Replacement of fishmeal with maggot meal in the diets of Nile tilapia, Oreochromis niloticus. World Aquacult 35: 52-54.

31. Yılmaz S, Ergün S (2013) Chickweed (Stellaria media) leaf meal as a feed ingredient for tilapia (Oreochromis mossambicus). J Appl Aquaculture 25(4): 329-336.

32. St-Hilaire S, Sheppard C, Tomberlin JK, Irving S, Newton L, et al. (2007) Fly prepupae as a feedstuff for rainbow trout, Oncorhynchus mykiss. J World Aquacult Soc 38(1): 59-67.

33. Kroeckel S, Harjes AG, Roth I, Katz H, Wuertz S, et al. (2012) When a turbot catches a fly: Evaluation of a pre-pupae meal of the Black Soldier Fly (Hermetia illucens) as fish meal substitute-Growth performance and chitin degradation in juvenile turbot (Psetta maxima). Aquaculture 364: 345-352.

34. Sing KW, Kamarudin MS, Wilson JJ, Sofian-Azirun M (2014) Evaluation of Blowfly (Chrysomya megacephala) maggot meal as an effective, sustainable replacement for fishmeal in the diet of farmed juvenile red tilapia (Oreochromis sp.). Pakistan Veterinary Journal 34(3): 288-292.

35. Lock E, Arsiwalla T, Waagbø R (2015) Insect larvae meal as an alternative source of nutrients in the diet of Atlantic salmon (Salmo salar) postsmolt. Aquac Nutr 22(6): 1202-1213.

36. Magalhães R, Sánchez-López A, Leal RS, MartínezLlorens S, Oliva-Teles A, et al. (2017) Black soldier fly (Hermetia illucens) pre-pupae meal as a fish meal replacement in diets for European seabass (Dicentrarchus labrax). Aquaculture 476: 79-85.

37. Iaconisi V, Marono S, Parisi G, Gasco L, Genovese L, et al. (2017) Dietary inclusion of Tenebrio molitor larvae meal: Effects on growth performance and final quality treats of blackspot sea bream (Pagellus bogaraveo). Aquaculture 476: 49-58.

38. Piccolo G, Iaconisi V, Marono S, Gasco L, Loponte R, et al. (2017) Effect of Tenebrio molitor larvae meal on growth performance, in vivo nutrients digestibility, somatic and marketable indexes of gilthead sea bream (Sparus aurata). Anim Feed Sci Tech 226: 1220.

39. Tran G, Heuzé V, Makkar H (2015) Insects in fish diets. Anim Front 5(2): 37-44. 


\section{International Journal of Oceanography \& Aquaculture}

40. Zarai Z, Frikha F, Balti R, Miled N, Gargouri Y, et al. (2011) Nutrient composition of the marine snail (Hexaplex trunculus) from the Tunisian Mediterranean coasts. J Sci Food Agr 91(7): 12651270.

41. Merdzhanova A, Dobreva DA, Stancheva M, Makedonski L (2014) Fat soluble vitamins and fatty acid composition of wild black sea mussel, rapana and shrimp. Sciendo 25(1): 15-23.

42. Tsi C, Ma X, Lou Z, Zhang F (1983) Illustrations of the Fauna of China (Mollusca). Beijing science Press 2: 1150.

43. Lai K, Pan C (1980) The Rapana shells of Taiwan. Bulletin of Malacology, Republic of China 7: 27-32.

44. Drapkin E (1953) A new mollusc in the Black Sea. Priroda 9: 92-95.

45. Vink R, Nieweg D, Post H (2005) Rapana venosa (Valenciennes, 1846): a new invasive species for the Netherlands (and England?). Spirula 345: 152-155.

46. ICES (2004) Alien species alert: Rapana venosa (Veined Whelk). In: Mann R, (Eds.), ICES Cooperative Research Report No 264, pp: 14.

47. Saglam H, Kutlu S, Dagtekin M, Bascinar S, Sahin A, et al. (2015) Population biology of Rapana venosa (Valenciennes, 1846) (Gastropoda: Neogastropoda) in the south-eastern Black Sea of Turkey. Cah Biol Mar 56(56): 363-368.

48. Chung E, Kim S, Kim Y (1993) Rapana venosa (Gastropoda: Muricidae), with species reference to the reproductive cycle, depositions of egg capsules and hatching of larvae. Korea J Malacol 9(2): 1-15.

49. Saglam H, Duzgunes E (2007) Deposition of egg capsule and larval development of Rapana venosa (Gastropoda: Muricidae) from the south-eastern Black Sea. J Mar Biol Assoc UK 87: 953-957.

50. Harding JM, Mann R (2005) Veined rapa whelk (Rapana venosa) range extensions in the Virginia waters of Chesapeake Bay, USA. J Shellfish Res 24: 381-385.

51. Mann R, Harding JM (2003) Salinity tolerance of larval Rapana venosa: implications for dispersal and establishment of an invading predatory gastropod on the North American Atlantic coast. Biol Bull 204(1): 96-103.

52. Zolotarev V (1996) The Black Sea ecosystem changes related to the introduction of new mollusc species. Marine Ecology 17(1-3): 227-236.

53. Berndt T, Bourdon N, Buchanan R, Doane A, Doyle L, et al. (2014) An Introduction To Marine Invasive Species. Marine Sciences Student Projects Pp: 100.

54. Harding JM, Mann R (1999) Observations on the biology of the veined rapa whelk, Rapana venosa (Valenciennes, 1846) in the Chesapeake Bay. J Shellfish Res 18(1): 9-17.

55. Savini D, Castellazzi M, Favruzzo M, OcchipintiAmbrogi A (2004) The alien mollusc Rapana venosa (Valenciennes, 1846; Gastropoda, Muricidae) in the northern Adriatic Sea: population structure and shell morphology. Chem Ecol 20(1): 411-424.

56. Savini D, Occhipinti-Ambrogi A (2006) Consumption rates and prey preference of the invasive gastropod Rapana venosa in the Northern Adriatic Sea. Helgoland Mar Res 60(2): 153-159.

57. Parliament E (2011) Plenary sitting. Pp: 1-14.

58. Janssen R, Knudsen S, Todorova V, Hoşgör AG (2014) Managing Rapana in the Black Sea: stakeholder workshops on both sides. Ocean \& Coast Manage 87: 75-87.

59. Anderson JS, Lall SP, Anderson DM, McNiven MA (1995) Availability of amino acids from various fish meals fed to Atlantic salmon (Salmo solar). Aquaculture 138(1-4): 291-301.

60. Xu H, Zhao M, Zheng K, Wei Y, Yan L, et al. (2017) Antarctic krill (Euphausia superba) meal in the diets improved the reproductive performance of tongue sole (Cynoglossus semilaevis) broodstock. Aquac Nutr 23(6): 1287-1295.

61. Karr-Lilienthal LK, Grieshop CM, Spears JK, Fahey GC (2005) Amino acid, carbohydrate, and fat composition of soybean meals prepared at 55 commercial US soybean processing plants. J Agr Food Chem 53(6): 2146-2150.

62. Westendorf M, Dong Z, Schoknecht P (1998) Recycled cafeteria food waste as a feed for swine: nutrient 


\section{International Journal of Oceanography \& Aquaculture}

content digestibility, growth, and meat quality. J Anim Sci 76(12): 2976-2983.

63. Westendorf M (2000) Food waste as animal feed: an introduction. In Food Waste to Animal Feed, Iowa State University Press, Pp: 3-16, 69-90.

64. Samuels WA, Fontenot JP, Allen VG, Abazinge MD (1991) Seafood processing wastes ensiled with straw: utilization and intake by sheep. J Anim Sci 69(12): 4983-4992.

65. Myer RO, Brendemuhl JH, Johnson DD (1999) Evaluation of dehydrated restaurant food waste products as feedstuffs for finishing pigs. J Anim Sci 77(3): 685-692.

66. Arvanitoyannis IS, Kassaveti A (2008) Fish industry waste: treatments, environmental impacts, current and potential uses. Int J Food Sci Technol 43(4): 726745 .

67. Jackson A, Newton R (2016) Project to model the use of fisheries by product in the production of marine ingredients, with special reference to the omega 3 fatty acids EPA and DHA. Institute of Aquaculture, University of Stirling, UK, IFFO, The Marine Ingredients Organisation, pp: 1-14.

68. Edward J, Raghunathan C, Rajamanickam S, Ayyakkannu K (1996) An artificial prawn feed formulation with non-edible meat of gastropods Chicoreus virgineus and Rapana rapiformis. Indian J Mar Sci 25: 248-252.

69. Luo F, Xing R, Wang X, Peng Q, Li P (2017) Proximate composition, amino acid and fatty acid profiles of marine snail Rapana venosa meat, visceral mass and operculum. J Sci Food Agric 97(15): 5361-5368.
70. Dolashka P, Moshtanska V, Borisova V, Dolashki A, Stevanovic S (2011) Antimicrobial proline-rich peptides from the hemolymph of marine snail Rapana venosa. Peptides 32(7): 1477-1483.

71. Idakieva K, Siddiqui NI, Meersman F, De Maeyer M, Chakarska I, et al. (2009) Influence of limited proteolysis, detergent treatment and lyophilization on the phenoloxidase activity of Rapana thomasiana hemocyanin. Int J Biol Macromol 45(2): 181-187.

72. Dolashka P, Dolashki A, Beeumen JV, Floetenmeyer M, Velkova L, et al. (2016) Antimicrobial activity of molluscan hemocyanins from Helix and Rapana snails. Curr Pharm Biotechnol 17(3): 263-270.

73. Dolashka P, Velkova L, Shishkov S, Kostova K, Dolashki A, et al. (2010) Glycan structures and antiviral effect of the structural subunit $\mathrm{RvH} 2$ of Rapana hemocyanin. Carbohydr Res 345(16): 23612367.

74. Iliev I, Toshkova R, Yossifova L, Zacharieva S, Dolashka-Angelova P, et al. (2008) Haemocyanins from Rapana venosa and Helix vulgaris display an antitumour activity via specific activation of spleen lymphocytes. C R Acad Bulg Sci 61(2): 203-210.

75. Stenzl A, Dolashki A, Stevanovic S, Voelter W, Aicher W, et al. (2016) Cytotoxic effects of Rapana venosa hemocyanin on bladder cancer permanent cell lines. J US China Med Sci 13: 179-188.

76. Badiu DL, Balu AM, Barbes L, Luque R, Nita R, et al. (2008) Physico-chemical characterisation of lipids from Mytilus galloprovincialis (L.) and Rapana venosa and their healing properties on skin burns. Lipids 43(9): 829-841. 